\title{
ПОТРЕБИТЕЛЬСКОЕ КРЕДИТОВАНИЕ В РФ: АКТУАЛЬНАЯ ДИНАМИКА, ПРОБЛЕМЫ И УГРОЗЫ ДЛЯ ЭКОНОМИКИ
}

\author{
(c) 2020 Мухаметшин Дамир Фаридович \\ кандидат экономических наук, доцент кафедры управления человеческими ресурсами \\ Казанский (Приволжский) федеральный университет, Россия, Казань \\ (c) 2020 E-mail: DFMuhametshin@kpfu.ru \\ (c) 2020 Валитов Гаяз Шамилевич \\ студент \\ Высшая школа экономики
}

В ходе данного исследования нами будет рассмотрен рынок потребительского кредитования в России. За последние несколько лет в России в связи с политической и экономической рецессиями колебались большинство банковских ставок, включая ставки по розничному кредитованию. С 2017 года в стране произошёл резкий скачок объемов необеспеченного кредитования среди населения. Данный рост может привести к негативным последствиям, которые могут оказать отрицательное влияние в целом на всю российскую экономику.

Ключевые слова: Потребительское кредитование, экономика, банковская ставка, обеспеченность кредитования

Потребительские кредиты в России, динамика, факторы, воздействующие на объем кредитования физических лиц.

Потребительское кредитование является важным финансовым инструментом, влияющим на развитие российской экономике. Объем выдач потребительских кредитов составляет $69 \%$ от всего неипотечного кредитования [1, стр 5]. Такой большой масштаб объясняется быстротой получения заемных средств, а также без необходимости предоставления обеспечения и сбора большого количества документов в отличии от ипотечного кредитования и автокредитования. История потребительских кредитов в РФ ведет свое начало с конца 1990-х годов, когда банк «Русский стандарт» предложил гражданам брать целевые необеспеченные кредиты, которые можно было оформить за 30 минут и без поручительства, людей даже не отпугнула высокая стоимость обслуживания заемных средствам (кредитная ставка составляла 70-80\%) [2, стр 27]. Выгоду от таких кредитов кроме банков получили и торговые организации, так как розничные кредиты содействовали увеличению объемов продаж. Спустя время потребительское кредитование стало нецелевым, однако кредитование в торговых организация стабильно росло, так как в некоторых случаях владельцы магазинов получали больший доход от предо- ставлений кредитов совместно с банками чем от реализации товаров. В 2019 года доля кредитов в магазинах составила 1,6\% [1, стр 5]. В настоящее время рынок розничных кредитов развивается примерно в таком же объеме, что и до рецессии в 2014-2015 годах. Ежегодный прирост количества оформленных потребительских кредитов составляет $24 \%$, хотя в 2014 году ежегодный прирост был равен отрицательному показателю [3, стр 22]. Объемы выдаваемых розничных необеспеченных кредитов, в отличии от ипотечных кредитов, которые растут линейно даже в периоды рецессий непосредственно зависят от колебаний макроэкономических показателей. Например, до 2014 года объем потребительских кредитов имел постоянный рост. В докризисный период общий размер выданных банками населению необеспеченных кредитов составлял 3,2 трлн. руб в год, а совокупный банковский портфель необеспеченных кредитов был равен 7,7 трлн. руб, что составляло 9,9\% от ВВП. Даже сейчас в период роста рынок потребительского кредитование не может приблизиться к такому же отношению кредитного портфеля к ВВП (8,2\% от ВВП, при банковском портфеле 8,5 трлн. руб). Однако общий объём выданных средств в кредит физическим лицам значительно вырос в посткризисный период, с 1,7 трлн. руб в 2015 году до 4,3 трлн. руб в 2018, и на данный момент 
Источник: Сбербанк [1, стр 3], расчёты: Frank Research Group Источник: Сбербанк [1, стр 3], расчеты: Банк России, Росстат

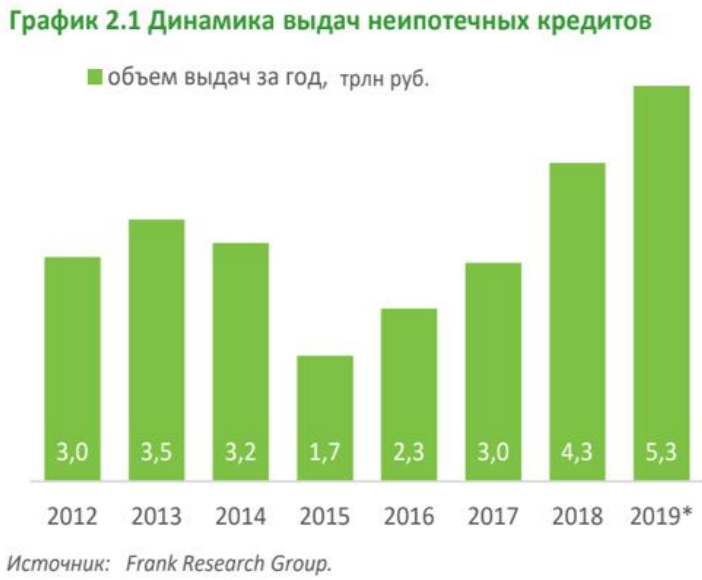

График 1.1 Динамика рынка неипотечного кредитования

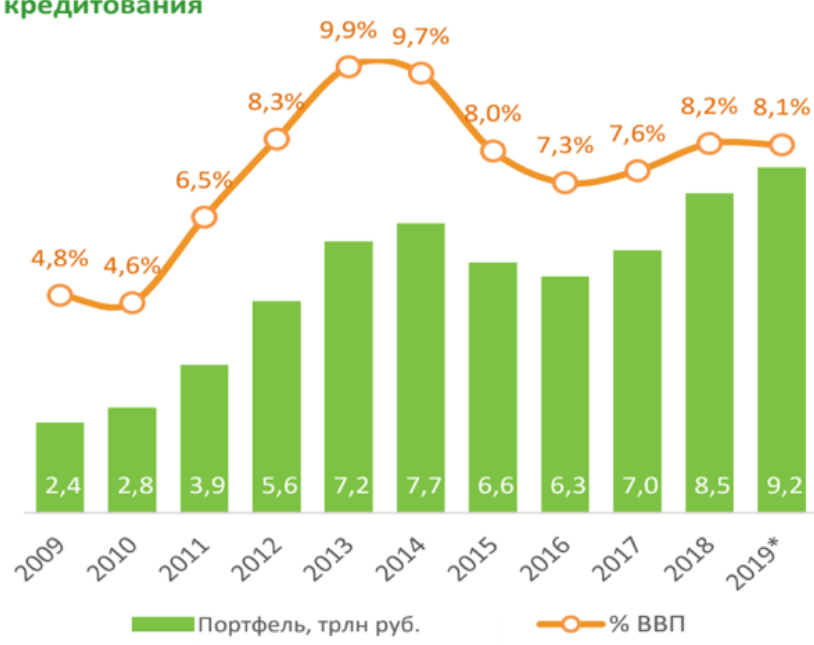

данный показатель опережает показатель 2013 года. Пик рынка российского потребительского кредитования в последние года пришелся на второе полугодие 2018 года, когда кредитный портфель банков за полгода увеличился на $12 \%$, а в первом полугодие 2019 года рост портфеля уменьшился в сравнении с концом в 2018 года, однако остался на достаточно высоком уровне и составил $11 \%$ [4]. Большая динамика роста кредитования в первом полугодии 2019 года наблюдалась у АО «Тинькофф банк» (40\%) и ПАО «МТС-банк» (33\%), однако некоторые банки показывают тенденцию на сокращение темпов кредитования, например АО «ОТП банк», АО «Кредит Европа банк» и ПАО КБ «Восточный», у которых объем розничного кредитования граждан сокращался в среднем на 2\% [4]. На такое поведение индикаторов и в целом на развитие рынка потребительского кредитования влияют следующие факторы:

1) Увеличение номинальных доходов населения. В данном случаем мы будем рассматривать именно увеличение номинальных доходов, а не реальных, потому что возрастание номинального дохода подталкивает потенциальных заёмщиков, в особенности низкооплачиваемых работников, к новым приобретениям, улучшениям условий жизни, так как они из-за увеличения дохода чувствуют, что будут способны расплатиться с долгом. Согласно данным Росстата, в России за 2018 год номинальная средняя заработанная плата увеличилась на $11,6 \%$, а в начале 2019 еще на 8\% [5]. Согласно Сбербанку, средняя заработанная плата клиентов, которые в 2017 году получали менее 15000 руб, в 2018 году увеличилась на $42 \%$ [1, стр 9]. Главной причиной данного скачка является приравнивание МРОТ к прожиточному минимуму и последовавший вслед за этим рост минимальной заработанной платы на 48\%. Однако, несмотря на значительный рост номинального дохода населения, реальные доходы продемонстрировали большое падение в 2015-2017 годах, а в первом квартале 2019 года они понизились на 2,3\% в годовом выражении (новая методология Росстата) [5]. По мнению первого зампреда ЦБ Дмитрия Тулина, люди устали жить в условиях постоянного снижения реальной доходности, поэтому они берут кредиты у банков, чтобы поддерживать такой же уровень потребления, который был в докризисный период [6].

2) Понижение стоимости кредитов. Процентная ставка потребительского кредита имеет связь с уровнем инфляции в стране и ключевой ставкой ЦБ. В разгар кризиса в 2014 года ЦБ пришлось «таргетировать» инфляцию с помощью повышения размера ключевой ставки. До 2013 года на рынке потребительских кредитов была тенденция на понижение процентных ставок (в 2013 году средняя ставка по стране составляла 13\% годовых), а в 2014-2015 годах из-за разгоревшегося в стране кризиса средняя процентная ставка по кредитам в стране повысилась почти в 2 раза, при этом ключевая ставка ЦБ увеличилась с 5\% в 2013 году до 17\% в конце 2014 года. Данное решение ЦБ привело к ростам процентов в банках по кредитам и депозитам. Тогда, при уровне инфляции в 15\%, средневзвешенный 


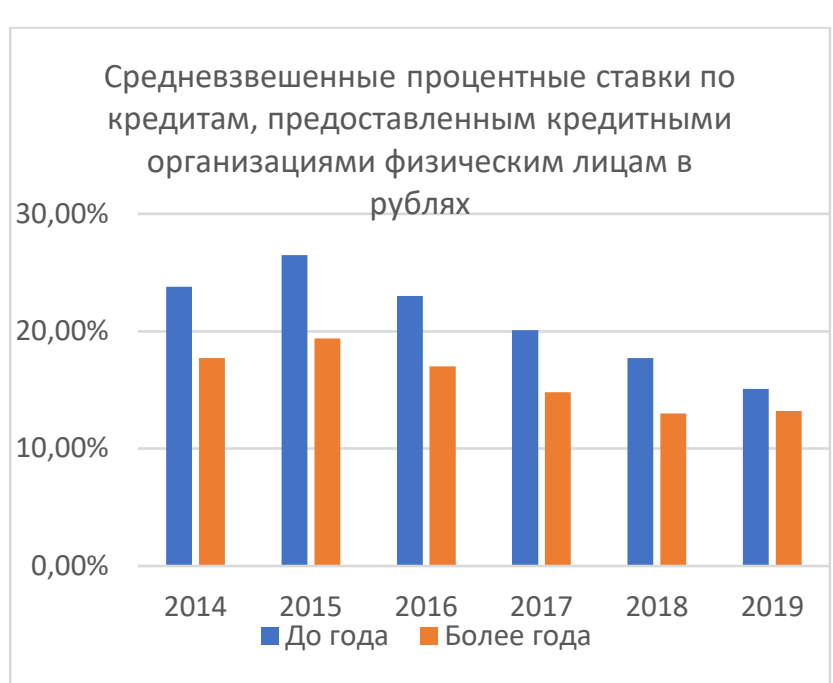

Источник: Банк России [7]

процент по розничным кредитам был равен $26 \%$ до года и $19,4 \%$ более года, а по депозитам средняя ставка выросла до $12 \%$. Однако ближе к концу 2016 года, когда прошёл пик роста инфляции и рубль стал более стабильным, ЦБ понижает ключевую ставку и следовательно проценты по кредитам снижаются. В результате, к концу 2019 году средняя ставка по стране составила 13,2\% для кредитов более года и $15 \%$ для кредитов до года, однако в некоторых банках можно найти предложения по предоставлению кредита за $10-11 \%$ годовых, что не так уж сильно превышает ипотеку и автокредитование, по которым требуется обеспечение. 25 октября 2019 года ЦБ понизил ключевую ставку до 6,5\%, однако не последовало значительной реакции от процентных ставок по потребительским кредитам, в отличии от ставок по депозитам и ипотечным кредитам, которые понизились на достаточно высокий уровень [9]. Например, на 2 декабря ставки по ипотечному кредитованию упали на уровень меньше 9\%, а ставки по депозитам были снижены банками в среднем на $0,3-0,4 \%$ [9]. Причиной противоположенной реакции рынка розничного необеспеченного кредитования является то, что большинство банков предвидело понижение ключевой ставки и заранее понизило процентные ставки по потребительским кредитам, а также то, что проценты по таким кредитам уже долгое время находятся на меньшем уровне (по динамике) в сравнении с депозитами и ипотечными кредитами.

3) Рост средней суммы кредита. Согласно анализу ВЦИОМ, на сегодняшний день каждая вторая семья в России (51\%) имеет непогашен-

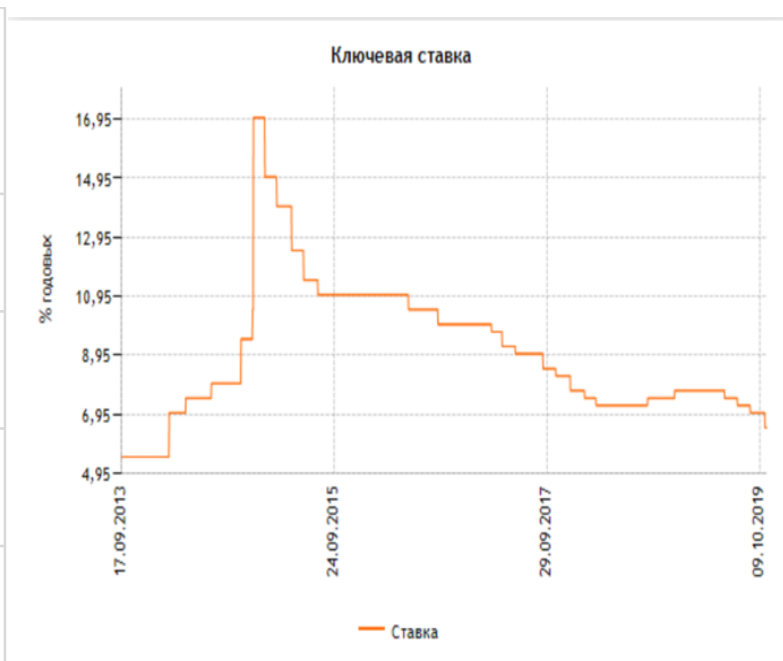

Источник: Банк России [8]

ный кредит, так же статистика показывает, что наиболее активной частью населения, использующей заёмные средства, являются люди в возрасте от 25 до 34 лет (72\%), однако, несмотря на достаточно высокий уровень доли населения, имеющей задолженность по розничным кредитам, за последние 2 года количество россиян, у которых есть розничный кредит снизилось на 6\% [10]. Следовательно, высокий объём потребительского кредитования объясняется тем, что повышается средний размер одного кредита, что и доказывает Национальное бюро кредитных историй. В начале 2018 года средний размер потребительского кредита составлял 137 тыс. руб. и за год средний размер увеличился на 30 тыс. руб., составив 178,6 тыс. Согласно исследованию НБКИ уже в январе-августе 2019 года средний размер розничного кредита составил 180,4 тыс. руб, на 12,7\% превышая показатель прошлого года за тот же период (160,1 тыс. руб.) [19]. Самый высокий средний объём розничного кредита у заёмщиков с 40 до 49 лет - 229,6 тыс. руб., а самый низкий у людей моложе 25 лет 85,6 тыс. руб. [19] Большое влияние на повышение среднего размера кредита оказала политика Центрального банка по ограничению выдачи потребкредитов на короткий срок и под высокие проценты (повышение надбавок к коэффициентам риска). Из-за довольно парадоксальной ситуации на рынке кредитования в России, когда проценты по розничным необеспеченным кредитам начали приближаться к процентам по обеспеченным (базовые ставки по ипотеке чуть превышают $10 \%$, а проценты по потребительским кредитам, в большинстве случаев на сумму 


\section{Средний размер потребительского кредита, в тыс. руб.}

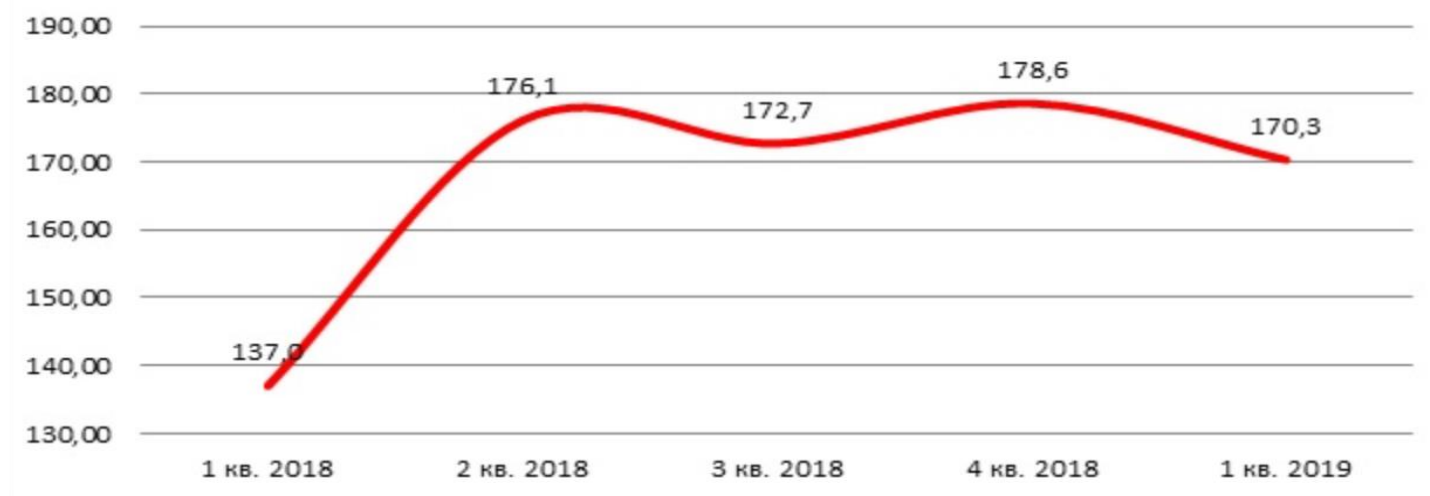

Источник: НБКИ [11]

более 1 миллиона, составляют 11\%), на рынок стала заходить более состоятельная аудитория [1, стр 17]. Данная ситуация объясняется фактором процентного риска: более короткие розничные кредиты быстрее приспособились к низкому уровню инфляции в стране. Также за последний период времени значительно вырос средний срок продолжительности потребительского кредита, со 170 месяцев (14 лет) в 2017 году до 215 месяцев (18 лет), хотя первоначально потребительские кредиты позиционировались как «краткосрочные кредиты» [1, стр 14]. На данный момент проценты по потребительским кредитам находятся на том же уровне, что и до периода рецессии в российской экономике, однако за период в 6 лет произошел значительный рост цен на товары и услуги, вызванный большим уровнем инфляции и ростом номинальной зарплаты. Все эти факторы объясняют почему ожидаемый объём кредитования физических лиц в 2019 году превышает тот же показатель в 2013 году на 1,8 трл руб. [1, стр 3] Также можно выделить второстепенные причины повышения объема кредитования: эффективная маркетинговая кампания банков (реклама, ведение страниц в социальных сетях), развитие онлайн банкинга (в некоторых банках розничные кредиты можно получить прямо в онлайн приложении, то есть фактически без самого визита в банк), а также повышение финансовой грамотности населения.

\section{Проблемы потребительского кредитова- ния в РФ.}

1) Повышение объёмов кредитования населения может привести к большему количеству проблемных кредитов. Одной из потенциальных проблем, на которую может повлиять развитие розничного кредитования, является закредито- ванность населения. Согласно выводам всемирного банка и Роспотребнадзора, более 9\% семей, которые брали потребительские кредиты, имеют просроченную задолженность перед банком, $10 \%$ семей оформляют новый кредит или проводят рефинансирование кредита во избежание проблем с просроченной задолженностью [12]. Данная ситуация привела к тому, что более четверти российских семей тратят на погашение кредита, на оплату ЖКХ и повседневные траты семьи более $75 \%$ совокупного дохода семьи. Наращивание темпов потребительского кредитования в стране может стать угрозой финансовой стабильности в стране в случае изменения макроэкономических условий [12]. По мнению всемирного банка, более $26 \%$ заёмщиков являются уязвимыми, то есть при изменение макроэкономических показателей и уменьшении доходов, им будет труднее погашать свои задолженности по кредитам [3, стр 23]. Тем не менее, риски, к которым ведёт высокий объём кредитования, ограничиваются ЦБ РФ и ГД РФ. Государственная дума рассматривает принятие закона, согласно которому заёмщикам, у которых выплаты по кредитам составляют более $50 \%$ от семейного бюджета будет запрещено брать кредиты [3, стр 23]. Центральный банк уже с 2013 года вводит ограничения по необеспеченным кредитам физическим лицам: увеличиваются надбавки к коэффициентам риска по очередным кредитам заёмщика с высокой полной стоимостью (ПСК) [1, стр22]. Смысл ПСК заключается в том, на сколько процентов заемщики переплатят банку. Сначала ограничивались только кредиты с ПСК больше 25\%, но с 2018 года ЦБ было принято повысить коэффициенты риска с ПСК более $10 \%$.

Самая высокая надбавка будет устанавливаться для заёмщиков, которые берут кредит 
Таблица 22.1 Коэффициенты риска по потребительским кредитам в рублях

\begin{tabular}{l|c|c|c|c}
\multicolumn{1}{c|}{ пск } & с 2013 & с 2014 & с 2018 & с 2019 \\
\hline 10\%-15\% & $100 \%$ & $100 \%$ & $100 \%$ & $150 \%$ \\
\cline { 2 - 5 } $15 \%-20 \%$ & $100 \%$ & $100 \%$ & $100 \%$ & $170 \%$ \\
\cline { 2 - 5 } $20 \%-25 \%$ & $100 \%$ & $100 \%$ & $110 \%$ & $200 \%$ \\
$25 \%-30 \%$ & $110 \%$ & $100 \%$ & $140 \%$ & $230 \%$ \\
\hline $30 \%-35 \%$ & $110 \%$ & $100 \%$ & $200 \%$ & $300 \%$ \\
\hline $35 \%-40 \%$ & $140 \%$ & $140 \%$ & $600 \%$ & $600 \%$ \\
\hline $40 \%-45 \%$ & $140 \%$ & $140 \%$ & $600 \%$ & $600 \%$ \\
\hline $55 \%-50 \%$ & $170 \%$ & $300 \%$ & $600 \%$ & $600 \%$ \\
\hline $50 \%-55 \%$ & $170 \%$ & $300 \%$ & $600 \%$ & $600 \%$ \\
\hline $55 \%-60 \%$ & $170 \%$ & $300 \%$ & $600 \%$ & $600 \%$ \\
\hline $560 \%$ & $200 \%$ & $600 \%$ & $600 \%$ & $600 \%$ \\
\hline
\end{tabular}

Источник: Банк России.

Источник: Сбербанк[1, стр 22] расчёты: Банк России

по ставке 25-30\% в год и с долговой нагрузкой более $80 \%$. Меры, принятые ЦБ по увеличению надбавок по коэффициентам риска приводят к понижениям процентных ставок по кредитам, что сдерживает долговую нагрузку населения на макроуровне. Увеличение надбавок по коэффициентам риска приводит к тому, что российские банки повышают запасы капитала по покрытиям возможных потерь, что должно помочь банкам избежать рисковых ситуаций, которые были в 2014-2015 годах [13, стр 13]. На май 2019 года суммарный размер капитала по 24 крупнейшим банков России (кроме Сбербанка) составлял 190 млрд. руб, а в следствии ужесточения требований размер составил 288 млрд. руб. [13, стр 13]. Также с этого года ЦБ вводятся ограничения на соотношение кредитных платежей к доходам заёмщиков (ПДН). Эта мера будет ограничивать выдачу кредитов, если на их погашение уходит большая часть доходов заёмщиков. Так с октября 2019 года все банки и микрофинансовые организации обязаны предоставлять ЦБ РФ отчетность по данному соотношению [3, стр 23]. Показатель долговой нагрузки населения по необеспеченным потребительским кредитам в России находится на среднем уровне по сравнению с другими странами, так как в других странах, особенно в европейских, процентные ставки по кредитам ниже российских, тем самым обслуживание кредитных средств гораздо дешевле для европейских заёмщиков [13, стр 10]. В 2016-2017 годах долговая нагрузка населения была стабильной, это было обусловлено значительным снижением процентных ставок по потребительским кредитам, а также снижением ставок во всей эконо-
Таблица 22.2 Надбавки к коэффициентам риска с учетом Показателя долговой нагрузки (ПдН)

\begin{tabular}{|c|c|c|c|c|c|}
\hline \multirow[b]{2}{*}{ ПСК } & \multicolumn{5}{|c|}{ Интервалы Пдн } \\
\hline & до 50 & $50-60$ & $60-70$ & $70-80$ & $80+$ \\
\hline $0-10$ & 30 & 60 & 70 & 90 & 110 \\
\hline $10-15$ & 50 & 70 & 80 & 100 & 120 \\
\hline $15-20$ & 70 & 110 & 130 & 140 & 160 \\
\hline $20-25$ & 100 & 150 & 170 & 180 & 200 \\
\hline $25-30$ & 130 & 180 & 190 & 200 & 220 \\
\hline $30-35$ & 200 & 210 & 220 & 230 & 250 \\
\hline $35+$ & 500 & 500 & 500 & 500 & 500 \\
\hline
\end{tabular}

Источник: Банк России.

Источник: Сбербанк[1, стр 22]расчёты: Банк России

мике в целом [13, стр 10]. Однако с 2018 года рост кредитования физических лиц в стране сопровождается ростом долговой нагрузки населения на макроуровне, так как проценты по кредитам стабилизировались, но продолжается рост объёмов кредитования населения [13, стр 10]. Также в первом квартале 2019 года произошло резкое повышение объёмов выдач необеспеченных кредитов гражданам с показателем долговой нагрузки более $80 \%$. Рост доли коррелирует с повышением в конце 2018 года - начале 2019 года количества выданных кредитов на срок более 5 лет на 8-10\% при показателе прошлого года за тот же период в 3-5\%. По этой причине ЦБ разрабатывает меры по ограничению возможной практики банков по понижению ПДН граждан за счёт длинного срока кредитования.

Чем больше долговая нагрузка заёмщика, тем больше нагрузки приходится на капитал банка. Одним из недостатков расчёта ПДН является то, что банкам трудно высчитать точный номинальный доход потенциального заёмщика, так как большая часть россиян не могут подтвердить свои доходы, поэтому в большинстве случаев в качестве номинального дохода гражданина регулятор рекомендует брать средний показатель по региону [14]. Однако, с 1 октября те заёмщики, которые имеют «серый» доход и не могут документарно подтвердить свои реальные доходы для подсчёта ПДН будут ограничены в выдачах новых необеспеченных займов [20]. Несмотря на опасение экспертов ЦБ, по поводу роста долговой нагрузки населения, исследование Сбербанка показывает, что на данный момент рост данного показателя и повышение объемов 


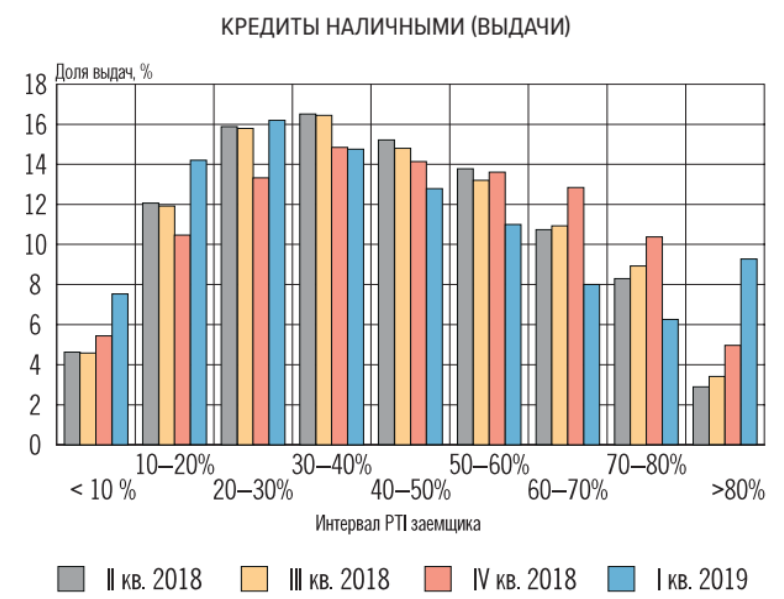

кредитования не влияет на выплаты гражданами своих задолженностей [1, стр 23]. Средней платеж по розничным кредитам среди клиентов Сбербанка в 2,3 раза превышает размер планового платежа и в результате это приводит к тому, что российскому рынку кредитования присуще, то, что реальный срок выплаты кредита ниже контрактного: даже в группе с маленькими объемами кредитов и низкими доходами доля досрочных выплат остаётся высокой [1, стр 23]. Средний объём просроченной задолженности, согласно отчётностям топ банков по МСФО, снизился до 5,4\% на середину 2019 года, однако уже к концу первого полугодия тренд на сокращение

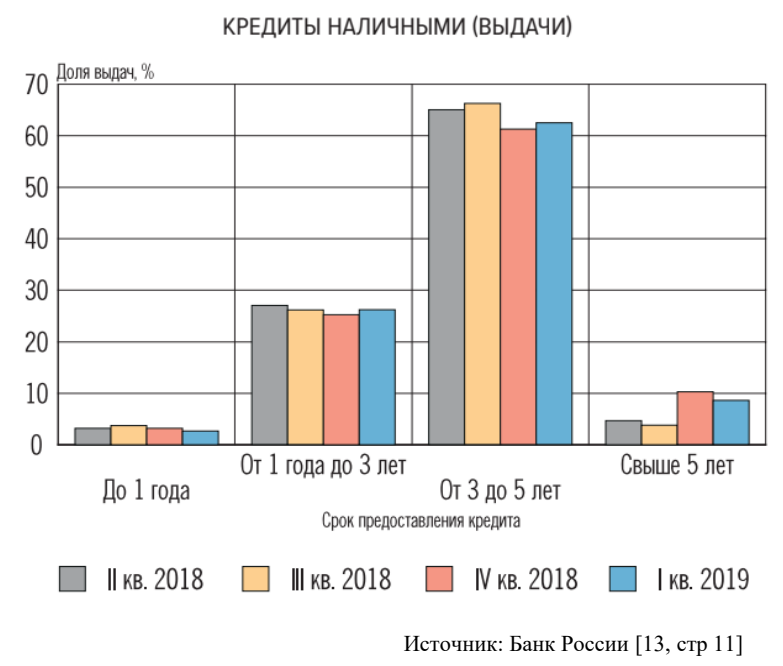

просроченной задолженности прекратился [4]. Но грамотнее анализ качества кредитов проводить с помощью стоимости рисков, которые показывают величину потенциальных потерь по займам, потому что многие банки списывают проблемные задолженности на заранее сформированные резервы, а также передают задолженности по кредитам коллекторским агентствам [4]. Величина стоимости рисков (COR) выросла на $0,6 \%$ и в 2019 году составила в среднем 6,9\% по всем розничным банкам. Повышение данного показателя обуславливается ростом уровня дефолтности выданных кредитов, что является ранним фактором ухудшения качества кредитов.

График 3. Несмотря на снижение доли просроченной задолженности, наблюдается рост стоимости риска по потребительским кредитам

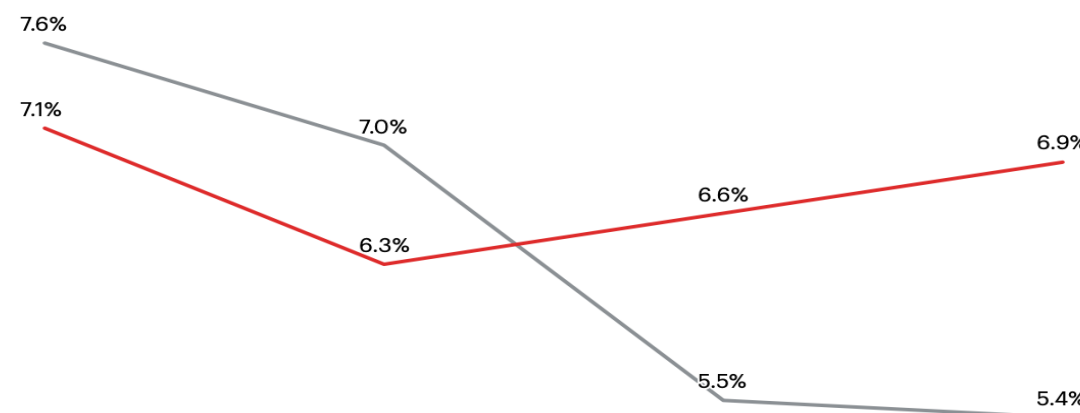

2016 
Центральный банк выделяет рискованную группу заёмщиков, которые находятся под угрозой потенциального дефолта по потребительским кредитам перед банками. Согласно ЦБ, 3,7 миллиона человек привлекают новые кредиты, не погасив свои прошлые задолженности [20]. Совокупный долг данной доли заёмщиков с 2017 года увеличился с 0,9 триллиона рублей до 2,2 триллионов рублей [20]. Несмотря на то, что на данный момент данные заёмщики не имеют задержек выплат задолженности, в будущем, при условии роста объемов потребительского кредитования, данные клиенты могут стать проблемными для банков. Тем самым, введение ПДН является оптимальным для решения проблемы выдач необеспеченных кредитов сомнительным заёмщикам. .

2) Дифференциация уровня долговой нагрузки граждан в зависимости от места проживания. На данный момент признаки перегрева рынка потребительского кредитования наблюдаются в регионах, где население берёт займы на покупку товаров первой необходимости, тем самым эта тенденция демонстрирует нам, что определенная доля граждан в нашей стране берёт займы не только для того, чтобы сохранять прежний уровень потребления, но и на покупку жизненно необходимых товаров [20]. Следовательно, в России различается уровень закредитованности населения в зависимости от региона. Логично, что долговая нагрузка граждан богатых регионов будет ниже чем у граждан бедных регионов ввиду значительных различий в доходах. В 2018 году отношение кредитов банков к доходам населения составила более $40 \%$ в 5 регионах: Иркутская область (40\%), Тюменская область (41\%), Республика Чувашия (43\%), Республика Калмыкия (52\%) и Республика Тыва (53\%) [1, стр 23]. Однако высокий уровень пропорции кредитов к доходам населения не означает высокий уровень просроченных платежей в регионе среди заёмщиков. Так, самая большая доля просроченных платежей в регионах с маленьким кредитным портфелем, однако высокая доля просроченных обуславливается плохой кредитной дисциплиной, это проявляется в кавказкских республиках [1, стр 23].

3) Увеличение рефинансируемых кредитов. Согласно исследованию бюро кредитных историй Эквифакс, за 2016-2017 года в России значительно увеличилась доля заёмщиков, которые покрывают (производят рефинансирование за- долженности) свои кредиты, взятые под большие проценты, с 10\% в 2016 году и до 20\% в 2017 году [13, стр 11]. Основной причиной такого резкого скачка является понижение процентных ставок в эти года, а также в среднем ставки по рефинансируемым кредитам чуть ниже чем по обычным. На данный момент доля рефинансируемых кредитов остаётся на уровне 2017 года [13, стр 11]. У банков есть специальные предложения по рефинансированию кредитов, но более популярным методов погашения более дорогих кредитов, по данным Сбербанка, остаётся оформление новой задолженности под более низкий процент. Например, в 2018 году среди клиентов Сбербанка в 86\% случаев для рефинансирования были оформлены новые кредиты [1, стр 15]. Тем самым, высокий уровень досрочного погашения кредитов не означает понижения задолженности населения перед банками. Однако из-за введения многочисленных ограничений центральным банком, рынок рефинансируемых кредитов в 2020 году может столкнуться с локальным кризисом. Так, заёмщики, у которых расплата по долгам связана с перекредитованием и рефинансированием своих прошлых задолженностей, могут столкнуться с проблемой оформления новых кредитов [15]. Раньше заёмщики могли взять новый кредит под меньший процент или объединить все свои задолженности в один кредит, однако из-за новых правил заёмщики могут столкнуться с ограничениями.

\section{Влияние потребительского кредитова- ния на российскую экономику.}

Развитие розничного кредитования в России оказывает значительное влияние на ВВП. Согласно Центральному банку, рост ВВП, при отсутствии поддержки в виде кредитов, мог бы снизиться до нуля. Рост кредитования населения увеличивает спрос на товары и услуги, а это, тем самым, влияет на показатели роста российской экономики, поэтому закредитованность российских граждан на данный момент никак нельзя назвать причиной падения экономики, а наоборот, развитие розничного кредитования является источником поддержки экономического роста в России [16]. Например, при маленьком экономическом росте в последние года, проведение жесткой денежно-кредитной и бюджетной политики в стране позволило стабилизировать инфляцию на уровне $4 \%$, а также значительно понизить ставки по розничному кредитованию. 
Потребительские кредиты увеличивают способность граждан в удовлетворении материальных потребностей. В 2019 году заёмщики Сбербанка в большинстве случаев оформляли необеспеченные потребкредиты для проведения ремонта недвижимости (14\% с учётом снятия наличных), это связано с тем, что в последние года в нашем обществе условия проживания становятся важнее места проживания и тем, что большинство купленных квартир выдаются только с чистовой отделкой.

Также своей популярностью в России пользуются кредиты на покупку непродовольственных товаров длительного использования: электроники, одежды, мебели (11\%), а также на покупку автомобилей (10\%), несмотря на то, что существуют более дешёвые обеспеченные кредиты на покупку машин (автокредитование). В большинстве крупных магазинов, как мы уже отмечали это ранее, возможно оформить потребительский кредит, что позволяет гражданам делать приобретения в отсутствии достаточного объема средств. Одной из особенностей российской экономики является увеличение потребления при снижении реальных доходов населения. С 2017 года граждане России стали активно тратить свои накопления. Например, если норма накопления среди населения в 2016 году превышала 17\%, то уже к началу 2018 года данный показатель снизился до 10\%, а в нынешнем году норма накопления достигла исторического минимума $-8 \%$ [16]. Динамика заработанной платы в России в 2019 году, по мнению экспертов, вряд ли повторит её рост в прошлом году, так как рост НДС и пенсионного возраста имеют отрицательные эффекты на динамику, а также из-за того, что эффект высокой бюджетной базы 2018 года по причине дорогостоящего проведения чемпионата мира по футболу и запаздывающих затрат по национальным проектам [16]. Следовательно, в данных условиях кредитные средства остаются единственным источником поддержания уровня потребления населения при отрицательной динамике реальных доходов. В последние годы динамика объемов потребительского кредитования в России непосредственно коррелирует с ростом влияния розничного кредитования на покупки населением товаров и услуг, то есть с ростом кредитного импульса. В докризисный период (до 2014 года) уровень потребления был достаточно высоким, $12 \%$ от ВВП, при этом кредитный импульс был низким в соотношении к потреблению. Это обусловливалось хорошими макроэкономическими показателями в стране в те года, а также стабильными реальными доходами населения. В 2017-2018 более половины потребления населения пришлось на импорт, что является вычетом из ВВП. Следуя данной предпосылке, можно сделать предположение о том, что заёмные средства граждан тратятся примерно в такой же пропорции. Тем самым оценка кредитного импульса снижается на $0,5 \%$ от ВВП [13, стр 16]. После начала кризиса потребление в стране резко упало, а причинами данного падения являются рост цен на товары и услуги вследствие инфляции, последовавшей за
График 19.1 Структура прироста расходов по картам в период после взятия кредита по товарным категориям

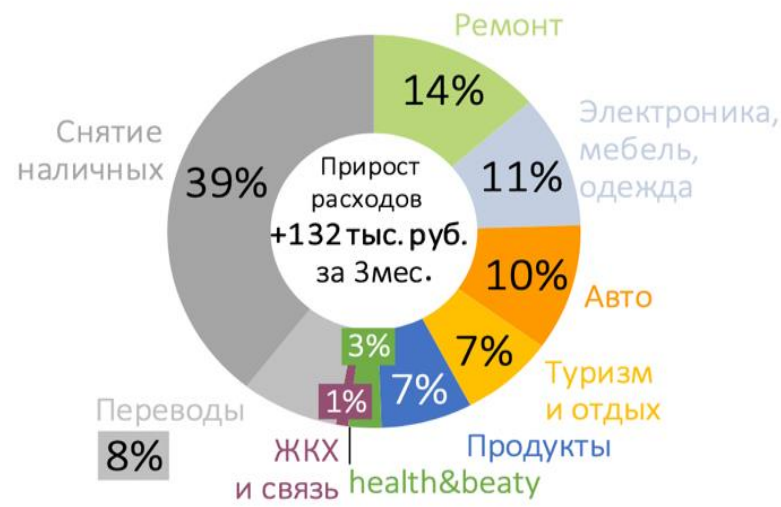

Источник: Сбербанк.

Источник: Сбербанк[1, стр 20]
График 19.2 Структура прироста расходов по картам в период после взятия кредита по товарным категориям (без учета наличных)

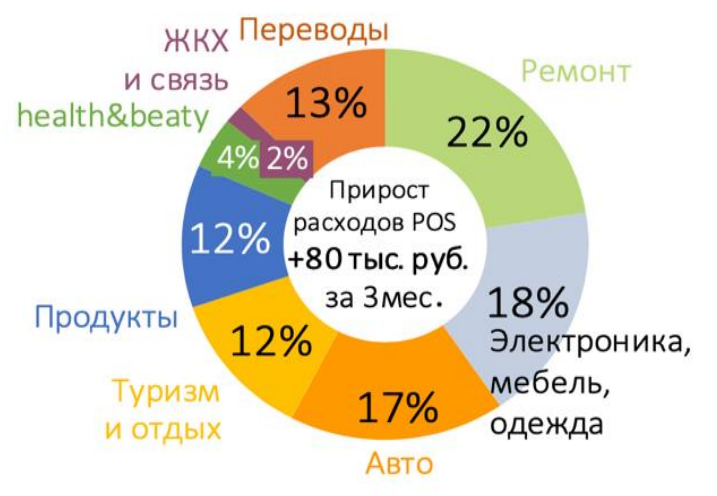

Источник: Сбербанк.

Источник: Сбербанк[1, стр 20] 


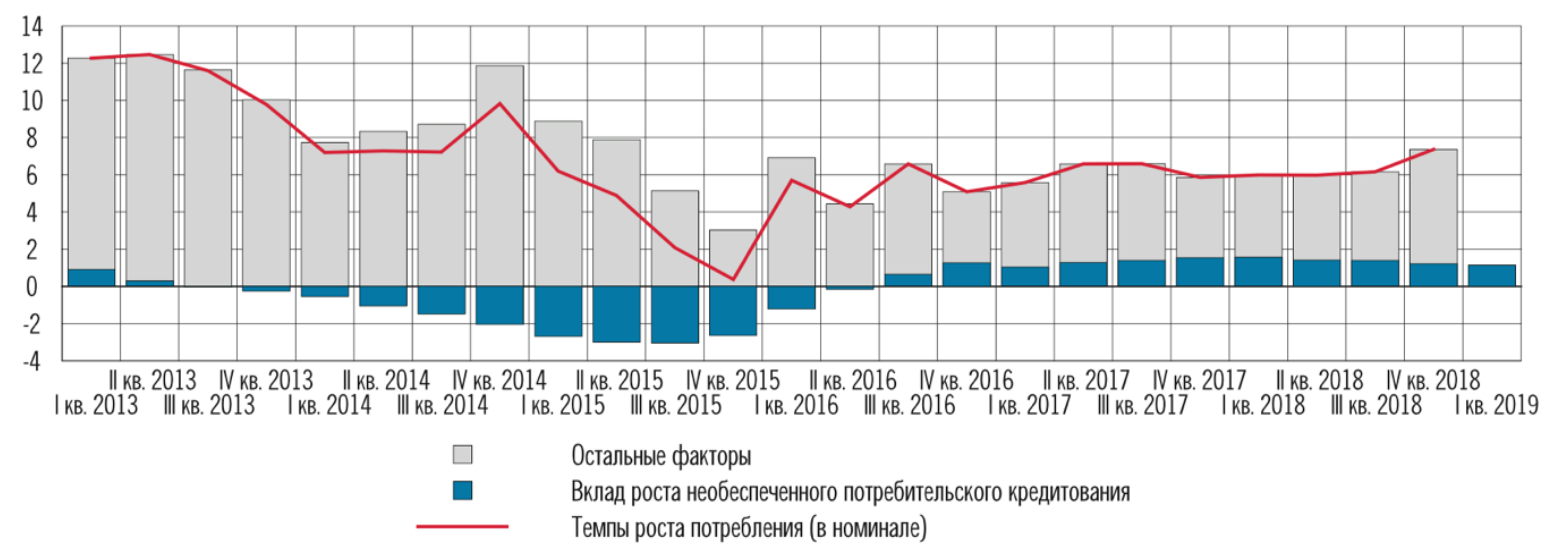

Источник: расчеты Банка России.

Источник: Банк России [13, стр 16]

этим понижение реальной заработанной платы, а также резкий рост процентов по кредитам. После восстановления российской экономики, уровень потребления имеет небольшой рост, поддерживаемый потребительским кредитованием, однако на потребление российского население значительную роль могут оказать другие факторы, то есть факторы, определяющие экономический рост. Например, рост доходов населения до обязательных выплат будет поддерживать уровень потребления [13, стр 16]. В 2018 году кредитный импульс составил 1,5\% от потребления домашних хозяйств, однако в 1 квартале 2019 года влияние розничного кредитования на потребление снижалось, а кредитный импульс достиг 1\%[13, стр 16]. Российский рынок потребительского кредитования зависит от внешних факторов, они исторически являются одними из источников возникновения проблем в этой среде экономики. Например, в 2008-2009 и в 20142015 годах на фоне внешних рисков, в России было значительное понижение развития экономики, а за этим последовало понижение реальных доходов населения, тем самым это привело к понижению способности населения платить по своим задолженностям [13, стр.17].

Угрозы российской экономике из-за роста объема потребительского кредитования.

1) Потенциальное появление пузыря на рынке потребительского кредитования. Появление пузыря на рынке потребительского кредитования - одно самых вероятных последствий закредитованности населения. Если доля потре- бительских кредитов в экономике страны при условии высокой долговой нагрузки населения становится слишком высокой, а у финансовой сектора нет определенных «буферов» противодействия такому пузырю, то возникновение пузыря может иметь негативное влияние на финансовый сектор, экономику страну и даже привести к рецессии [13, стр 17]. Одним из примеров возникновения долгового пузыря в стране является ипотечный кризис в США. Тогда задолженность к располагаемым доходам населения выросла с 90\% в 2004 году до 130\% в 2007 году, а в России данный показатель с вырос с $24,3 \%$ в 2017 году до 29,9\% в начале 2019 года. Объёмы розничного кредитования в России показывают внушительный рост в последние несколько лет из-за перехода российской экономики к посткризисной фазе. Рынок потребительского кредитования растёт быстрее чем российская экономика. Учитывая низкие накопления населения, реальные доходы россиян, мы можем сделать вывод, что у большинства граждан нет «подушки безопасности». Задолженности населения растут быстрее их номинальных доходов: отношение платежей по кредиту к доходам заёмщиков на конец 2018 года увеличилось на $0.8 \%$ и составило $8.4 \%$, тем самым это является подтверждением роста плановых платежей населения по кредитам [16]. В первое полугодие 2019 года более трети необеспеченных заимствований были выданы гражданам и домохозяйствам, у которых плановые ежемесячные платежи по задолженностям составляют более $60 \%$ от ежемесячных доходов. По поводу данной негатив- 
ной ситуации министр экономического развития РФ Максим Орешкин считает, что Россия в ближайшие 3 года может столкнуться с угрозой появления пузыря в виде потребительского кредитования [18]. Могут пострадать не только граждане и домохозяйства, но и в целом российская экономика: динамика ВВП может обвалиться на 3\%, в экономике начнётся рецессия, которая может перерасти в полномасштабный кризис [18]. Нововведения центрального банка, которые ограничивают выдачу необеспеченных займов, определенно, помогут в затормаживании роста кредитования населения, однако такие изменения нужно было вводить несколько лет назад. По моему мнению, перспектива пузыря имеет место быть в нашей экономике, так как при условии снижения реальной доходности населения и увеличения объемов кредитования граждан в ближайшие несколько лет, у граждан будут снижаться накопления, так как большая часть средств будет идти на погашение старых задолженностей, а также большая часть выданных кредит будет браться не под покупку определенного товара, а на рефинансирование старых задолженностей. Учитывая то, что розничное кредитование поддерживает уровень ВВП в стране, при развитии пузыря кредиты, наоборот, могут оказать отрицательное влияние на ВВП, так как закредитованность граждан снизит спрос населения на товары и услуги. В связи с введением ЦБ ограничений по выдачам кредитов, 2020 году нашу страну ожидает понижение роста объ- емов необеспеченного кредитования. По оценкам ЦБ, в 2020 году рост составит $10-15 \%$, хотя за январь-сентябрь 2019 задолженности населения выросли на 21.1\% [14]. Сокращение роста задолженностей по кредитам в несколько раз является шоковым сценарием для всех субъектов экономики. Из-за этого понизится покупательская способность домохозяйств и неизбежным будет обвал потребительской активности населения. Также колоссальный рост объёмов кредитования негативно влияет на реальные доходы населения, ведь процентные выплаты считаются как расходы, поэтому эти расходы снижают реальные доходы населения [17]. Однако согласно анализу Сбербанка, риски потребительского кредитования в нашей стране достаточно малы из-за того, что, как было уже отмечено в нашей работе, рост кредитования происходит благодаря понижению стоимости обслуживания кредитов, а также повышению сроков кредитования. Также в России довольно высокий уровень выплат по задолженностям. Но именно повышение объемов задолженности, на наш взгляд, является главной проблемой в потребкредитования, так как из-за этого заёмщики становятся уязвимыми от многих макроэкономических показателей: размер ставки, уровень безработицы.

2) Угроза банковскому сектору. На данный момент угроза банковскому сектору не является такой же горячей темой как угроза появления пузыря на рынке потребительского кредитования, однако существуют множество негативных по-

\section{ВКЛАД В ПРИРОСТ НЕОБЕСПЕЧЕННОГО ПОТРЕБИТЕЛЬСКОГО КРЕДИТОВАНИЯ ПО БАНКОВСКОМУ СЕКТОРУ (\%) \\ Рис. 1}

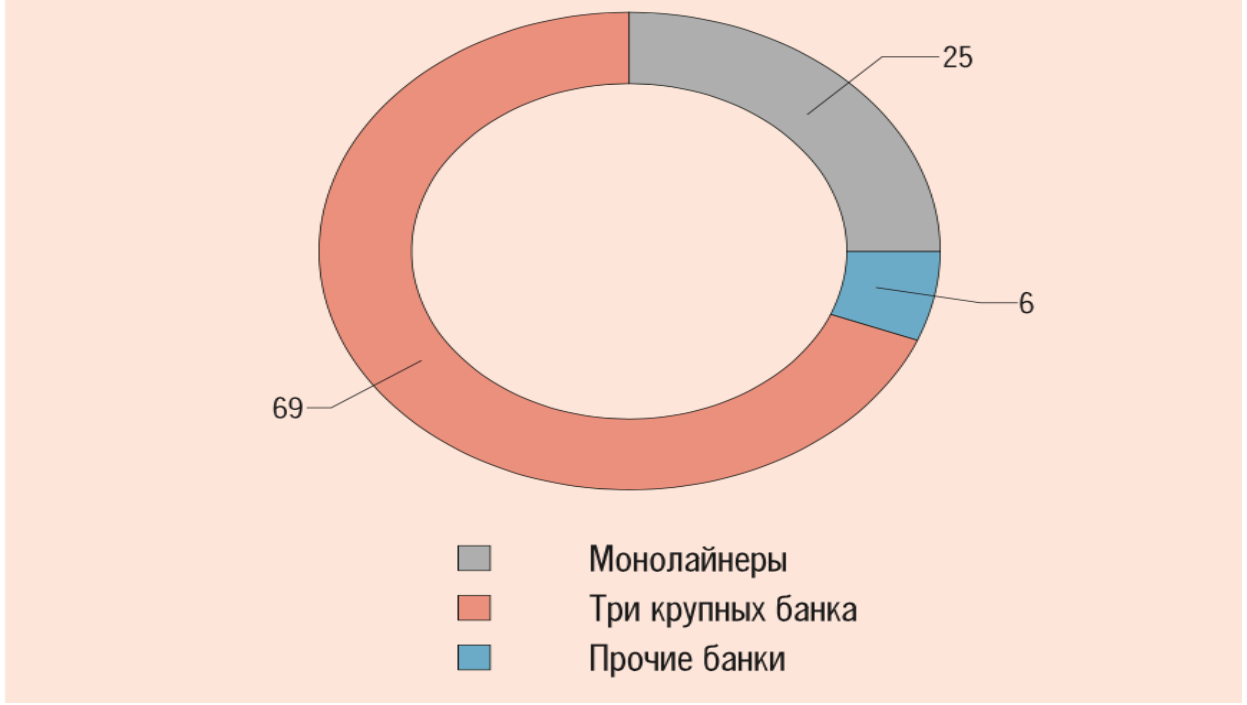


следствий для деятельности банков вследствие закредитованности российских граждан. Около 69\% роста долгов по необеспеченным розничным кредитам начиная с 2017 года обеспечили 3 самых крупных универсальных банков России (ПАО «Сбербанк», ПАО «ВТБ», АО «Газпромбанк), около 25\% прироста уровня потребительского кредитования обеспечили монолайнеры, а 6\% остальными, более мелкими банками [13, стр 18]. Тем самым тот факт, что крупные и более надёжные заёмщики берут кредиты у более крупных государственных банков, может являться угрозой деятельности частных региональных банков, так как вероятность дефолта заемщиком банков 3 эшелона намного выше чем у клиентов крупных государственных банков. Также определенное влияние на деятельность банков имеет введение ЦБ ограничений на выдачу новых кредитов в виде повышения надбавок по коэффициентам риска. Данное нововведение может оказать негативный эффект на количество выданных кредитов банками, что может привести к разрушительным последствиям для банков, у которых объем денежных средств, привлеченных с помощью депозитов во много раз превышает собственный капитал [1, стр 26]. Также причиной такого же последствия может являться то, что в конце 2018 года население стало чистым заёмщиком у банков, то есть банковских кредитов стало больше чем депозитов [16]. То есть если население столкнется с проблемой выплат задолженностей по необеспеченным кредитам, то тогда некоторые банки будут вынуждены уйти с рынка. Несмотря на все риски, потребительское кредитование остаётся важнейшим механизмом в развитии банковского сектора страны. . В завершении нашего исследования мы должны рассмотреть перспективы развития розничного необеспеченного кредитования в России. В РФ при дальнейшей стабилизации экономической ситуации, т.е. уровень инфляции не будет иметь большого роста, а курс рубля будет крепким по отношению к иностранным валютам, рынок потребительского кредитования будет иметь развитие. Причиной этому будет являться стабильное снижение ключевой ставки Центрального Банка. Если результат по введению новых правил регулятором будет таким же, как и было запланировано ЦБ, то, определенно, динамика роста потребительского кредитования в стране снизится, однако, оно будет держаться на достаточно высоком уровне. Также при успешном введении правил, ограничивающих необеспеченное кредитование, в стране произойдет развитие обеспеченного кредитования, то есть автокредитования и ипотеки. При дальнейшем снижении стоимости обслуживания задолженностей, граждане будут рассматривать потребительские кредиты как обыкновенные инструменты планирования бюджета, так как при таких же процентных выплатах заемщики смогут взять кредит на более высокую сумму. Одним из последствий введения регулятором новых правил согласно прогнозам Fitch, в 2020 году темпы роста задолженностей по потребительским кредитам составит 15\%, что гораздо ниже показателей последних лет (20-25\%) [20]. Следовательно, благодаря новым требованиям регулятора, долговая нагрузка населения будет падать, а граждане будут более грамотнее подходить к принятию решений о взятии новых заЙмов.

\section{Основные выводы:}

1) Главной причиной роста объемов необеспеченного кредитования в России является низкая стоимость обслуживания кредитов. Стоимость кредитов непосредственно зависит от ключевой ставки ЦБ и уровня инфляции. Сейчас, когда ключевая ставка равна 6.5\%, а официальный уровень инфляции находится на уровне 4\%, ставки по потребительским кредитам и ипотекам находятся на исторически низком уровне.

2) Одним из основных фактором, влияющим на рост кредитования в стране является повышение номинальных доходов населения. Тем самым у граждан появляется мотивация оформлять новые кредиты. Однако реальные доходы россиян по динамике идут в противоположную сторону, тем самым рост задолженности населения является важнейшим источником потребления населения. Несмотря на некоторые положительные последствия роста розничного кредитования, повышение объемов необеспеченного кредитования физических лиц может привести к социальным угрозам, например сейчас у более чем половины семей есть непогашенная задолженность, многие семья тратят большую часть своего дохода на погашение кредитов. По нашему мнению, меры, введенные регулятором, должны понизить риски данных угроз в российской экономике.

3) На данные момент рост потребительского кредитования в России является важным 
фактором, влияющим на уровень потребления в стране и в целом на рост ВВП. Меры, принятые регулятором, по ограничению кредитованию приведут к сокращению роли потребительского кредитования в краткосрочном росте российской экономики, однако они могут привести к более стабильным показателям роста российской экономики в долгосрочном периоде, так появится устойчивость банковского сектора и сглаженная амплитуда кредитного цикла.

4) По нашему мнению, пузырь на рынке потребкредитования вполне имеет место быть, так как размеры задолженности населения за 2019 год выросли, однако из-за новых мер регулятора крупные заёмщики не смогут рефинансировать свои кредиты. Также из-за новых правил небезопасные заёмщики больше не смогут брать новые кредиты, тем самым это понизит спрос на рынке. На данный момент достаточно небольшой процент заёмщиков с просроченными задолженностями, но с годами эта доля может возрасти. А новые требования будут сдерживать рост доли заемщиков с просроченными кредитам, не выдавая подозрительным клиентам новые кредиты и в целом будут уменьшать риски развития пузыря на рынке потребкредитования.
5) Введение регулятором новых требований к заёмщикам должно привести к положительным результатам и помочь в противодействии к потенциальной угрозе раздутия пузыря на рынке потребительского кредитования в России. Показатель долговой нагрузки населения способен отразить множество тенденций и потенциальных угроз, к которым может привести согласие на выдачу кредита определенному заёмщику. На данный момент новые правила оказали умеренное влияние на деятельность банков, однако банки стали строже оценивать потенциальные риски при принятии решений о выдачи необеспеченных кредитов, что должно отразиться на объемах выдач кредитов в ближайшем будущем. Также во избежание дальнейшего повышения объёмов кредитования населения и долговой нагрузки населения, мы должны обратить своё внимание на финансовую грамотность россиян, ведь решение о взятии новой задолженности принимается непосредственно гражданином, следовательно люди должны объективно оценивать риски, которые они могут понести в случае оформления нового кредита. Тем самым регулятор и власти должны работать не только с банками, но и с населением.

\section{Библиографический список}

1. Есть ли «пузырь» на рынке потребительского кредитования? // Сбербанк //Дата обращения: 01.08.2019 // https://www.sberbank.ru/common/img/uploaded/files/pdf/analytics/market_bubble.pdf

2. Особенности потребительского кредитование в России в современных условиях // А.С Васильева, А.П.Васильев // Финансы и кредит // 2011 // https://cyberleninka.ru/article/n/osobennosti-potrebitelskogokreditovaniya-v-rossii-v-sovremennyh-usloviyah-1/viewer

3. Доклад об экономике России № 41 // Всемирный банк // Дата обращения: 10.06 .2019 // http://pubdocs. worldbank.org/en/908421560108417755/rer-41-russian.pdf

4. Обзор рынка потребительского кредитования по итогам 1-го полугодия 2019 года: скрытая угроза // Эксперт РА // Дата обращения: 03.10.2019 https://www.raexpert.ru/researches/banks/potrebcred_1h2019

5. Динамика среднемесячной номинальной и реальной начисленной заработной платы // Росстат // https:// www.gks.ru/bgd/free/b00_24/IssWWW.exe/Stg/d000/i000050r.htm

6. Банк России насторожили темпы роста розничного кредитования // Интерфакс // Дата обращения: 16.05.2019// https://www.interfax.ru/business/661359

7. Процентные ставки по кредитам и депозитам и структура кредитов и депозитов по срочности в целом по Российской Федерации // Банк России // https://www.cbr.ru/statistics/pdko/int_rat/

8. Ключевая ставка Банка России // Банк России // https://www.cbr.ru/hd_base/KeyRate/

9. Ипотечные ставки упали ниже 9\% // Ведомости // Дата обращения: 4.12.2019 // https:/www.vedomosti.ru/ finance/news/2019/12/04/817858-ipotechnie-stavki-upali-nizhe-9

10. Кредитная история: бум или статус-кво? // ВЦИОМ // Дата обращения: 7.08.2019 // https://wciom.ru/index. php?id=236\&uid $=9838$

11. Национальное бюро кредитных историй // Дата обращения: 22.04 .2019 https:/www.nbki.ru/company/ news/?id $=23715$

12. Всемирный банк сообщил о проблемах с кредитами у $60 \%$ заемщиков в России // РБК // Дата обращения: 11.06.2019// https://www.rbc.ru/finances/11/06/2019/5cfe78299a7947849bdd0216 
13. Ускоренный рост потребительских кредитов в структуре банковского кредитования: причины, риски и меры банка России // Доклад Центрального Банка // Дата обращения: Июнь 2019 года // https://www.cbr.ru/ Content/Document/File/72621/20190628_dfs.pdf

14. К чему приведут попытки ЦБ охладить рынок потребительского кредитования // Ведомости // Дата обращения: 10.10.2019 // https://www.vedomosti.ru/finance/blogs/2019/10/10/813391-tsb-ohladit-potrebitelskogo

15. Аналитики спрогнозировали кризис рефинансирования в российских банках // РБК // Дата обращения: 15.10.2019// https://www.rbc.ru/finances/15/10/2019/5da58fcd9a7947a7d9acaa81

16. Как потребительское кредитование влияет на жизнь людей // Ведомости // Дата обращения: 24.07.2019 // https://www.vedomosti.ru/economics/blogs/2019/06/24/804789-potrebitelskoe-kreditovanie

17. Реальные доходы не выдерживают кредитного давления // РБК// Дата обращения: 17.07.2019// https://www. rbc.ru/newspaper/2019/07/18/5d2f07959a79477db606e26f

18. «Пузырь лопнет»: когда Россия уйдет в рецессию // Газета Ру // Дата обращения: 21.07.2019 // https://www. gazeta.ru/business/2019/07/21/12513787.shtml

19. Национальное бюро кредитных историй // Дата обращения: 24.09.2019 // https:/www.nbki.ru/company/ news $/$ ?id=25618

20. Агентство Fitch предупредило о рисках перегрева розничного кредитования // Ведомости // Дата обращения: 02.11.2019// https://www.vedomosti.ru/finance/articles/2019/11/01/815345-fitch

21. Фахрутдинова Е.В., Камашева А. В., Валеев Э. Р. Статистический анализ дифференциации субъектов Российской Федерации по качеству жизни населения// Экономические науки. 2019. № 181. С.356-362.

22. Fakhrutdinova E., Severyanov O., Shigabutdinov A., Fakhrutdinov R. THE CRISIS OF 1998 IN RUSSIA: POLITICAL INTERVENTION AND ITS IMPLICATIONS// Life Science Journal. 2014. T. 11. № 6s. C. 442-447. 